\title{
The South Sudan Conflict: Continental and International Implications
}

\author{
John Max Chinyanganya \& Johns Mhlanga \\ National Defence College \\ University of Zimbabwe \\ Corresponding author: maxchiyanganya@yahoo.com \\ DOI: https://doi.org/10.32890/jis2015.11.7
}

\begin{abstract}
The South Sudan conflict which started in December 2013 is now entering its second year with continental and international implications far beyond comprehension in terms of human tragedy in one of the world's newest nations. Continued fighting between the government troops and the rebel forces has displaced more than 1000000 and killed over 100000 people while a humanitarian crisis threatens many more South Sudanese and their neighbouring states. The war risks tearing the country apart as well as creating a potential humanitarian crisis of epic proportions on neighbouring states. Hence, this article examines the continental and international implications of the current South Sudanese conflict which has roped in the African Union spearheaded by the Inter-Governmental Organization and the United Nations Mission in South Sudan. It argues that the heart of this post-independence conflict in South Sudan is the personal rivalry between President Salva Kiir and his former Vice President Riek Machar. This study attempts to provide a detailed outline of the South Sudanese civil conflict by conducting an in-depth investigation of secondary data as well as interviews with military peacekeepers imbued with experience on the ground in South Sudan. To address the conflict, this paper suggests that the international community and the country's leadership need to focus on resolving this personality-driven rivalry to pave way for sustainable peace in the country
\end{abstract}

Keywords: South Sudan conflict, Salva Kiir, Riek Machar, the Sudan People's Liberation Movement (SPLM), Ethnic targeting, the Inter-Governmental Authority on Development (IGAD), the UN Mission in South Sudan (UNMISS)

\section{Introduction}

The crisis in South Sudan which erupted on the 13th of December 2013 can be traced to the political dispute between President Salva Kiir and his former deputy, Reik Machar (The Sudd Institute, 2014). President Salva Kiir sacked Reik Machar after suspecting him of attempting to stage a coup d'état with ten other accomplices (Adebayo \& Nasiru, 2014). The political struggle between President Salva Kiir and his erstwhile former Vice President 
${ }^{1}$ John Max Chinyanganya \& ${ }^{2}$ Johns Mhlanga

Reik Machar degenerated into a complex ethnic affair that has escalated into a civil war which has since engulfed South Sudan (Lyman, 2014). This has been exacerbated by the fact that the key protagonists to the conflict come from two dominant ethnic groups in South Sudan (The Sudd Institute, 2014). It should be noted that President Silva Kiir is an ethnic Dinka while Reik Machar is from the Nuer ethnic group. In all intent and purpose, the crisis in South Sudan has evolved into a bloody ethnic conflagration that is threatening to destabilise not only the country, but also the Inter-Governmental Authority on Development (IGAD) region as a whole.

According to Adebayo and Nasiru (2014), the Dinka and the Nuer ethnic groups have a long history of conflict in South Sudan. Consequently, the two adversaries to the conflict accuse each other of taking deliberate actions aimed at diminishing the role of the other's ethnic group. The faction led by President Salva Kiir has emerged as the dominant force controlling the government and the army, the South Sudanese People's Army (SSPLA), whereas the faction led by Reik Machar is considered to be the rebel faction (Martell, 2014). The fighting between the government troops loyal to President Salva Kiir and the rebel faction led by Reik Machar have led to widespread killing of thousands of South Sudanese and the displacement of over 800000 people to neighbouring countries such as Ethiopia, Kenya, Sudan and Uganda (Adebayo \& Nasiru, 2014). While attempts are currently underway to bring peace to South Sudan, fighting still rages on across the country.

\section{The Conflict in South Sudan from the Perspective of National and Regional Security}

National security in South Sudan has been compromised by incessant fighting. This has tended to undermine government authority in maintaining peace and stability. Though the South Sudanese conflict is prima facie a localised intra state civil war, its impact has a regional dimension. The regional dimension the South Sudanese civil war has taken can be attributed to the outflow of refugees from the country to the whole of the Inter-Governmental Authority on Development (IGAD) member states. These refugees have used the host countries as platforms to support and launch attacks on the sides of the belligerent parties in South Sudan. The refugees have the potential to instigate revolts within the host countries which are also characterised by ethnic and religious divisions.

In this context, if the military, political, economic, societal, and environmental sectors are weak, this often results in domestic instability and national insecurity. For Buzan (1997), internal political insecurity can result from government or state policies that marginalise or discriminate against a group. Resistance to the government, efforts to overthrow it, or movements aimed at autonomy or independence may all threaten state stability and deepen state insecurity. From a societal point of view, security is the preservation of traditional practices, norms, customs and the religious orientations of the state's citizenry (Appleby, 2000). Thus, political conflict premised on the concept of ethnicity presents a major threat to the core values of a nation. All things considered, South Sudan is practically a victim of such a phenomenon. 
In a way, the post-independence conflict in South Sudan has implications for national security. Buzan and Waever (2003) refer to national security as absence of threat to the core values of a state. Broadly conceptualised, the concept of national security brings into context issues of national sovereignty and territorial integrity (Banks, 1984). National security in relation to sovereignty entails that the state through its government has overall authority and power to make decisions that bind all citizens of the state. Sovereignty is the ultimate expression of self-determination and self-rule of a country (Douglas 2012). Territorial integrity within the context of national security means that the state can defend its political borders from internal or external threats. However, national security is undermined in situations where there is conflict among groups within a state. The conflict situation in South Sudan which has taken an ethnic dimension has severely impaired the national security of that country. According to the International Crisis Group (2014), the South Sudanese Government has found it difficult to guarantee the safety and security of its people. In other words, the country is slowly becoming a failing state.

The conflict unfolding in South Sudan poses a major threat to national security which has the potential to undermine national sovereignty (US State Department, 2014). South Sudan has witnessed the emergence of a plethora of armed groups along ethnic allegiances. Each of these groups claims that they are fighting to redress perceived injustices, marginalisation and extermination perpetrated by the other groups (Healy, 2009). As indicated earlier, the Dinkas have coalesced around President Kiir's Sudan People's Liberation Movement (SPLM) while the Nuers have rallied behind Riek Machar's Sudan People's Liberation Movement (SPLM)-Opposition. Effectively, South Sudan has been partitioned into pockets of autonomous zones held by different ethnic militia armies (ICG, 2014). For example, the Unity State has fallen under the control of General James Koang Choul a former Sudan People's Liberation Army (SPLA) 4 ${ }^{\text {th }}$ Division commander (Healy, 2009:16). General Choul is the commander of the army as well as the military governor. This militarised kind of command structure has been replicated throughout the South Sudanese states. In the Upper Nile State, General Gathoth Gatkouth is the governor while a fellow military officer General Gabriel Tanginye is military commander (Healy, 2009). What this effectively means is that South Sudan lacks a central command structure that can guarantee the security of the state and protect its citizenry from attacks. The official government at Juba has failed to maintain security throughout South Sudan. Embattled President Kiir has attempted to forge an alliance with several groups from his Dinka ethnic group but this has failed (Douglas 2012). The factional tendencies among the many fighting groups in South Sudan have totally undermined national security.

The Marxist theory of conflict explains how national security is undermined in a conflict situation. According to the Marxist theory of conflict, structural disparities within society such as exploitation, marginalisation and exclusion are the basis for conflict within a polity (Adebayo \& Nasiru, 2014). National security is threatened when the groups within a polity feel that they are being marginalised from full access of national resources such as power and natural resources (Adebayo \& Nasiru, 2014). The situation prevailing in South Sudan 
${ }^{1}$ John Max Chinyanganya \& ${ }^{2}$ Johns Mhlanga

points to a struggle for the all-important resource that is political power. Structurally, power in South Sudan is dominated by the Dinka and their surrogate groups at the exclusion of equally powerful ethnic groups such as the Nuer, (Leornadi, Nelson, \& Santschi, 2010:). The Nuers feel ostracised from holding the influential levers of power at the government level. This has increased tension between the Dinkas and the Nuers. The personal conflict between President Salva Kiir and Riek Machar is a reflection of the tension between the two main ethnic groups in South Sudan. The national security in South Sudan has been undermined and the government is incapacitated to exercise power and control within the state.

The post-independence conflict in South Sudan is slowly evolving into a regional conflict. This raises the regional security complexes dimension which needs to be understood within the context of the Inter-Governmental Authority on Development (IGAD). Before dwelling on the regional security complexes, there is need to explicate what is meant by regional security. According to Brecher (2001), regional security refers to how security is clustered in geographically shaped regions. Buzan and Waever (2003) insist that to be a regional system, states should be geographically situated close to one another. Thus, a regional block must comprise two or more state actors. Member states must be in relatively geographic proximity to one another. The security interdependence within the regional level is more pronounced than at the global level (Buzan and Waever, 2003). A security region is defined by the patterns found within the security practices (Kellas, 1991). In recent times, the African continent has witnessed the emergence of regional blocs such as the Economic Community of West African States, (ECOWAS) in West Africa, Southern African Development Community (SADC) in Southern Africa and the Inter-Governmental Authority on Development (IGAD) in the Horn of Africa.

As noted by Buzan and Weaver (2003) the regional security complexes theory is concerned with how states within a regional bloc coalesce in order to increase their preservation. Often the states come together to advance collective security, economic integration, and political ties as neighbouring states (Webel \& Gatlung, 2007). The issue of security has become the major preoccupation of most countries. This is because intra-state and interstate conflicts have threatened national and regional security (Koos \& Gutschke, 2014). Conflicts can be intra state but with the movement of belligerent forces across borders, regional security is threatened. The cross border movements of the Uganda's Lord's Resistance Army (LRA) led by Joseph Kony clearly show the need to understand the regional security complexes if regional security is to be achieved and sustained (ICG, 2014). Buzan and Waever (2003) argue that, contrary to globalists who argue that security should be perceived from an international perspective, the regional security complexes holds that states within a given geographical area are viewed as being responsible for their security needs.

The conflict situation in South Sudan has necessitated the intervention of the regional body, namely, the Inter-Governmental Authority on Development (IGAD). There is increasing realisation within the Inter-Governmental Authority on Development (IGAD) region that 
continued conflict in South Sudan is likely to spill across to neighbouring countries. Sudan is accused of supporting rebel groups under the leadership of Sudan People's Liberation Army (SPLA) -Opposition led by Riek Machar. Meanwhile, Ethiopia is also accused of providing logistical support to the Sudan People's Liberation Army (SPLA) - Opposition. This has compromised the security situation in the Inter-Governmental Authority on Development (IGAD) region. Within the regional security complexes context, it is the duty of the regional body to maintain peace and security among its member states.

\section{Inter-Governmental Authority Development and its Role in Regional Security}

According to Healy (2009:7), the Inter-Governmental Authority on Development (IGAD) region is the successor organisation to Inter-Governmental Authority on Drought and Development (IGADD). This regional initiative was created in 1986 by drought stricken countries in the Horn of Africa namely; Djibouti, Ethiopia, Somalia, Kenya, Sudan and Uganda (IGAD, 2005). IGADD was created with a narrow mandate of dealing with issues of low politics such as drought, desertification, and attendant environmental issues (Healy, 2009:10). Apart from solely dealing with droughts, the Horn of Africa countries decided to broaden the mandate of their regional organisation to cover aspects such as security and integration. In March 1996, in Nairobi, Kenya, IGADD was transformed into the InterGovernmental Authority on Development (IGAD) (IGAD, 1996). The broad responsibility of the Inter-Governmental Authority on Development (IGAD) included issues of high politics such as conflict prevention, management and resolution of conflicts, humanitarian affairs, infrastructure development and food security (Healy, 2009). Since then, the InterGovernmental Authority on Development (IGAD) has played a crucial role in peace support missions in Somalia, Sudan and South Sudan. Currently, the organisation is hosting the on-going South Sudanese peace talks in Addis Ababa, Ethiopia. It has been instrumental in marshalling donor aid to the region through the Partners Forum.

The Inter-Governmental Authority on Development (IGAD) has played an active role in trying to end the conflict in Somalia. The conflict in Somalia can be traced to the overthrow of General Siad Barre in 1991 (Healy, 2009). Fighting erupted over the control of the capital, Mogadishu and in no time evolved into a conflict involving multiple clanbased factions. The emergence of Islam as a political force in Somalia gave the conflict a regional dimension with implications for Ethiopia and Kenya which have a sizeable number of Somali communities within their borders (ICG, 2014). At the international level, the conflict in Somalia attracted the USA interest and her Western allies who were concerned about the threat of international terrorism inspired by radical Islamic forces (US State Department, 2014). Since the fall of Siad Barre, Somalia has lacked a government that could exercise its membership to the Inter-Governmental Authority on Development (IGAD) and other international fora (Healy, 2009). As a result, the Inter-Governmental Authority on Development (IGAD) had the difficult task of dealing with state breakdown in Somalia. Though the conflict in Somalia is intra state it has regional and international implications 
${ }^{1}$ John Max Chinyanganya \& ${ }^{2}$ Johns Mhlanga

because of radical Islam espoused by the main warring factions (Tadesse, 2002). Countries such as Ethiopia, Kenya and Uganda feel threatened by the Islamic overtones of the conflict. Hence Ethiopia took a lead in trying to resolve the conflict in Somalia. However, the problem with the Ethiopian intervention in Somalia was that it was driven by national interest rather than regional concerns (Woodward, 2004:4). In 2000, the Inter-Governmental Authority on Development (IGAD) recognised the Transitional National Government (TNG) under the leadership of Abdulqasim Salat Hassan (Woodward, 2004). The Hassan TNG had the support of the Islamists and the business community in Mogadishu. It was however, viewed with suspicion by Ethiopia and the Somali's Reconciliation and Restoration Council headed by Abdulai Yusuf. According to Healy (2009) the TNG was accused of harbouring Islamist ambitions which was the driving force of international terrorism. Disunity among the Inter-Governmental Authority on Development (IGAD) countries particularly Kenya and Ethiopia has made it difficult for the regional bloc to resolve the Somali crisis.

The Inter-Governmental Authority on Development (IGAD) intervened in Sudan to bring to an end the 22 year old civil war. In 1983 Sudan was plunged into a civil war after the abolition of the federal arrangement that granted the southern states autonomy (Young, 2005). As a result, the John Garang led rebel army of southerners under the SPLM/A had to wage a bitterly fought civil war against the Islamic government in Khartoum for self-determination and autonomy. The Inter-Governmental Authority on Development (IGAD) intervention came when in 1993 General Umar al-Bashir requested neighbouring states, Ethiopia, Kenya, Uganda and Eritrea to resolve the crisis in Sudan (Healy, 2009). After years of protracted negotiations and mediation, the Inter-Governmental Authority on Development (IGAD) was able to come up with the Comprehensive Peace Agreement (CPA) which paved way for the liberation of South Sudan in 2011 (Response Plan, 2014). It is noteworthy that the volatile situation in the Horn of Africa saw governments changing, spontaneously leaving the settlement of regional security to individual member states. Kenya took a lead in resolving the crisis in Sudan because it had security worries regarding its territorial integrity that was coming under threat from Islamic-inspired incursions purportedly supported by the Arab government in Khartoum.

\section{The Comprehensive Peace Agreement (CPA) and the Transition to Statehood}

The history of South Sudan is incomplete without mentioning the Comprehensive Peace Agreement (CPA) of 2005. This historic agreement between the Sudanese government and the SPLA/M paved way for the full independence of South Sudan. One key feature of the CPA was that it was a regional initiative under the auspices of the Inter-Governmental Authority on Development (IGAD) and a consortium of donor countries such as the USA (Hwaly, 2009). Regional intervention by a regional bloc such as the IGAD clearly shows that the Sudanese conflict was no longer a localised conflict. It was also affecting the InterGovernmental Authority on Development (IGAD) countries who were hosting refugees fleeing the conflict in Sudan. Countries such as Uganda and Kenya have suffered internal 
strife as a result of the growing refugee crisis. Uganda has been worst affected as its own rebel Joseph Kony has taken advantage of the civil war in Sudan by making the southern part of the country as his sphere of military operations (ICG, 2014:23). It is noteworthy that countries in the IGAD region are experiencing both intra and international conflicts. Somalia is currently embroiled in a conflict involving the Islamic group Al- Shabaab whose attacks have spilled into Kenya which opposes the creation of an Islamic state in that country. Sudan itself is struggling to contain attempts of secession in the Darfur region. Eritrea and Ethiopia have emerged from a bitter civil war which resulted in the birth of the former.

The main feature of the CPA was that it provided for a referendum. Under the CPA referendum provisions, the people of South Sudan were to vote on whether to remain as part of Sudan or secede from the Islamic dominated north Sudan as an independent state (IGAD, 2005). The referendum which paved way for independence of South Sudan was held from the $9^{\text {th }}$ to the $15^{\text {th }}$ of January 2011 . By the $30^{\text {th }}$ of January 2011 results of the referendum showed that 98.83 percent of the southerners voted overwhelmingly to break away from Sudan (US Department State, 2014). With referendum results out at midnight $9^{\text {th }}$ of July 2011, South Sudan proclaimed itself an independent state under the name of the Republic of South Sudan. Subsequently, the new South Sudanese state became a member of the United Nations, African Union and the Inter-Governmental Authority on Development (IGAD). Contrary to general expectations independence did not bring peace and stability to South Sudan. There is still conflict with Sudan over how to share oil revenues given that $80 \%$ of the oil is from South Sudan (Deng, 2014). Border disputes between Sudan and South Sudan still persist. For example there is conflict over the border regions of Abyei and South Kordofan. Within South Sudan there are widespread ethnic tensions among the many ethnic groups. Inter-ethnic fighting has been recorded in the Jonglei state between the White Nuer Army of the Luo Nuer and the Murle over pastoral territory (US Department State, 2014). Ethnic conflict at the micro level reflected how divided South Sudan was along ethnic lines. At the governmental level the tension between the Dinka and the Nuer was to result in the outbreak of conflict in 2013.

Towards the signing of the CPA, Riek Machar and Lam Akol rejoined the mainstream Sudan People's Liberation Movement (SPLM) and shelved their differences preferring to focus on presenting a unified front and positioning themselves for political office in a new state (Blanachard 2014). The return of Riek Machar and Lam Akol to the Sudan People's Liberation Movement (SPLM) assisted in unifying the people of South Sudan ahead of the signing of CPA in 2005. Upon the tragic death of Sudan People's Liberation Movement (SPLM) leader, John Garang in July 2005, Salva Kiir became the Sudan People's Liberation Movement (SPLM) Chairman and President of the Government of Southern Sudan while Riek Machar was appointed Deputy President and Lam Akol became the Foreign Minister. The Sudd Institute (2014) argues that, the prospects for the referendum and independence of South Sudan propelled this unity. In order to foster unity between former protagonists, Salva Kiir chose Riek Machar as his running mate during the 2010 elections. The Sudan People's Liberation Movement (SPLM) leadership stood collectively and led the nation towards the 
${ }^{1}$ John Max Chinyanganya \& ${ }^{2}$ Johns Mhlanga

referendum and subsequent independence. Despite this development, simmering ethnic tensions, and bitter inter-personal rivalries remained present among the leadership. The situation got out of hand when President Salva Kiir distasted the political manoeuvrings of Riek Machar ahead of the 2015 Presidential Elections.

\section{Inter- Governmental Authority for Development Intervention}

The Inter-Governmental Authority on Development (IGAD) region has initiated mediation efforts to end the conflict by yielding the signing of the Cessation of Hostilities $(\mathrm{CoH})$ deal in January 2014 by all belligerent parties, fighting continues albeit in the low intensity configuration. According to Retired General Sumbeiyo (2015) “warring parties remain convinced of prospects for military victory and will not heed to the principle of no victor, no vanquish". There is a strong perception that the international community must exert more pressure on the warring parties. This may take the form of engaging the parties at the highest-level with a unified and unequivocal posture. The Chief Negotiator Seyoum Mesfin highlighted the point that, "It would be dangerous to be enticed to the suggestion that, any solution that seeks to exclude Salva Kiir and Riek Machar from having a role in the interim arrangement is unsustainable" (The Sudd Institute, 2014).

\section{Personal Greed of the Top Politicians in South Sudan}

Part of the explanation on the conflict in South Sudan is centred on personal greed and private interests of the dominant politicians in that country. The influential politicians in South Sudan seem to be pursuing power, authority and control of national resources for personal benefit than for the betterment of the country as a whole. Evidence shows that the dispute between the incumbent President Salva Kiir and his former Vice President Riek Machar has more to do with the personal interests of these two leaders than national interest. An academic from Sudan interviewed noted that President Salva Kiir wants to continue in office past 2015 against constitutional provisions and he is doing everything possible to frustrate Riek Machar. The animosity between the two influential leaders in South Sudan has played into the existing ethnic, political and economic defects that characterise this new state. Thus, the personal struggle for political dominance between Salva Kiir and Riek Machar has taken a momentum of its own which has aggravated the conflict in South Sudan. According to the International Crisis Group (2015) the power contest between and among the main political actors in South Sudan has become the prime driver of the conflict

\section{Political Power Dynamics}

The ICG (2014:4) notes that the political power dynamics unfolding in South Sudan are contributing to the conflict in Sudan. Problems stemming from political power dynamics include marginalization, injustice, exclusion, inequality in the distribution of services, 
and violent fanaticism (Jok 2014). While some of these problems were addressed by the Comprehensive Peace Agreement of 2005, there were some outstanding issues. These unsettled issues were to manifest themselves after independence (Douglas 2012). In the meantime, relations between political and military players in South Sudan are defined by differences that first surfaced during the Sudan civil war which started in 1983. These were subsequently followed by disputes regarding the vision and leadership of the movement. Riek Machar's split from John Garang in 1991 to form the Nuer dominated Nasir Faction was a reflection of a power contest in the Sudan People's Liberation Movement (SPLM). The split triggered ruthless cycles of violence between the Dinka and Nuer groups.

While the Nasir group re-joined the main Sudan People's Liberation Movement (SPLM), political rivalry continued through the Comprehensive Peace Agreement period well into independence. Joeng's (2010) point of view is that, "In conflict situations, power provides the actor with the capabilities to control the others' preference opportunities in one's own quest to achieve desired conditions." He goes further to say, "In producing the intended effects of power, one's action gets the other to behave in a way he wants." Thus, when President Salva Kiir dismissed his former Vice President Riek Machar and the entire cabinet including party Secretary-General, Pagan Amum, he wanted to frustrate Machar's aspirations to run as the Sudan People's Liberation Movement's (SPLM's) presidential candidate in the 2015 elections. Machar who had the support of 10,000 army troops mainly from the Nuer ethnic tribe rebelled against the government. Notably, many local ethnic Nuer militias joined his ranks. In addition, Reeve, (2012) notes that there is a prevalence of power struggle, marginalization and exclusion of individuals from political leadership. As President Kiir attempted to purge the contending officers from leadership positions, those politically excluded began to mobilize the people along ethnic lines, thereby igniting ethnic conflict in South Sudan. Thus, the root cause of the current ethnic violence in South Sudan is denial of political accommodation for certain political actors.

\section{Persistence of Inter and Intra Communal Conflict}

Analysts attribute the conflict in South Sudan to the persistence of inter and intra communal conflict. Retired Lieutenant Colonel Zecks Nyangari in an interview indicated that:

South Sudan witnessed persistent and increasingly violent inter and intra communal violence from 1983 through to the period of the CPA and independence. This situation precipitated disenfranchisement of communities, strained relationship between government and citizens, led to proliferation of arms and lack of the rule of law. The populations felt a sense of isolation and marginalization from the state (Nyangari 2015 int.).

In essence, analysis holds that in such a situation a sense of nationhood could not be adequately developed and sustained owing to growing insecurity and violence within the communities. These developments also served as powerful reminders of unresolved 
${ }^{1}$ John Max Chinyanganya \& ${ }^{2}$ Johns Mhlanga

tensions, and that political manipulation of local grievances could easily spill into the national realm. The documentary evidence resonates well with Karl Marx Theory which states that the cause of conflict in human beings' is naturally inclined aggressiveness if no other alternatives are available. Mankind is viewed to be in a 'state of nature' with a general irritable or aggressive inclination. In addition, Joeng (2013) says, "In multi-ethnic societies, disruption in the existing balance in ethnic privileges and power often provokes conflict which indicates that a social contract of co-existence between the communities and government is broken."

\section{Implications of the Post-independence Conflict on South Sudan}

Healy (2009: 9) notes that the current crisis has negatively affected South Sudan's sovereignty and stability. South Sudan is a nation gradually sliding towards a failed state like Somalia as conflict continues. A number of scholars argue that the conflict has caused serious suffering and destruction across the breadth and depth of South Sudan including neighbouring countries (Jok 2014; Koos \& Gutschke 2014; Mwanika 2012). Many innocent people have lost their lives, socio-cultural connections, and their possessions. According to Martell, 2014), the conflict in South Sudan has claimed the lives of over 1.3 million people. The horrible realities of civil hostilities are that they divide communities; heighten the levels of mistrust, and further ingrain social distrust, thereby making reconciliation impossible. In addition, the polarised civil war has damaged the societal fabric and communal relations, and the population is most likely to politically identify themselves along ethnic lines. Koos and Gutschke (2014) note that the conflict has seen the proliferation of small arms and numerous militia groups that overtly wreak mayhem in the communities targeted as well as straining social and political relations.

\section{Increased Political Fragmentation}

According to Adebayo and Nasiru (2014) the conflict in South Sudan has deepened political fragmentation as Sudan People's Liberation Movement (SPLM) leadership remains divided with competing agendas of the Inter-Governmental Authority on Development (IGAD) mediation effort in Addis Ababa. The belligerent parties use tactics of deliberate stalling, and lack clear purpose and agenda. The government refuses the inclusion of other smaller groups in the current talks in Addis Ababa, a proposal that has gained support of the InterGovernmental Authority on Development (IGAD) mediation process and the AU (Koos and Gutschke 2014). The SPLM intransigence has encouraged many smaller groups to disengage from the main Sudan People's Liberation Movement (SPLM) either to represent their grievances as separate entities or join Machar's group. On the other hand, Riek Marchar with his Sudan People's Liberation Movement (SPLM) Nasir is seen as more politically organized to the point of presenting his ideas for a new governance framework in the public domain. In an interview Retired Lieutenant Colonel Nyangari, working for the UNMISS Headquarters, had this to say: 


\begin{abstract}
South Sudan has lost an opportunity to build a voluntary united nation. It has lost an opportunity for reconciliation and an opportunity to build solid state institutions. It has also lost an opportunity to quickly transform into an economic muscle in its own right and as a regional economic powerhouse. The conflict has created irreparable mistrust among the ethnic communities in all the executive institutions and arms of government. The conflict may degenerate into "war-lordism", which is a recipe for a failed state. The international community, especially the UN appears to be losing hope on the once promising newest nation of the world. This creates donor fatigue and yet South Sudan's budget is heavily dependent on donor funding (Nyangari 2015 int.).
\end{abstract}

Politically, the conflicts often result in the weakening and possible collapse of the central government. To put it differently, conflicts have aided in the weakening of State institutions leading to the fall of Governments. For Mamdani (2001), internal conflicts led to the disintegration of both the ex-Soviet Union and former Federation of Yugoslavia in the 1990s. Meanwhile, the ethnic conflict in Somalia has also led to the collapse of state institutions rendering Somalia a stateless society. In much the same way, the Libyan conflict has destroyed the state institutions rendering the country ungovernable to the detriment of national security. These conflicts have also led to political ethnic polarity leading to loss of lives among the population. With this in mind, unless a possible break-though is found South Sudan may disintegrate in the same way as the former Yugoslavia, Soviet Union, Somalia, Libya, et cetera.

\title{
Humanitarian Crisis
}

The current conflict in South Sudan, has witnessed the death of an estimated 10,000 people as a result of fighting and approximately one million people displaced (UNHCR 2014). More than 400,000 people have fled to neighbouring Ethiopia, Kenya, Sudan and Uganda as refugees. This development can be likened to the humanitarian challenges experienced in the Burundi civil war which claimed over 200,000 lives by year 2000. Similarly, Liberia lost approximately 250,000 lives in the country's civil war between 1990 and 2004. Furthermore, during the civil war in Sierra Leone, approximately 200,000 people were killed between 1991 and 2001. In the final analysis, it is evident that conflicts result in huge human losses. This observation is corroborated by the Kenyan Charge de Affairs $\mathrm{P}$ L Nairimo who asserted that approximately 100000 people have died as a result of the conflict and more than 800000 people were displaced from their homes in seven of the ten South Sudan provinces.

\section{Regional Refugees Crisis}

The conflict in South Sudan has displaced approximately 800000 South Sudanese people (ICG, 2014). More than 400,000 people fled to neighbouring countries as refugees. Each of the following neighbours, namely; Kenya, Ethiopia, Sudan and Uganda has approximately 
${ }^{1}$ John Max Chinyanganya \& ${ }^{2}$ Johns Mhlanga

100,000 South Sudanese in their midst who fled their home country due to in-fighting and food insecurity (The Sudd 2014). In much the same way, in Sudan an estimated 4.7 million Sudanese were displaced during the nation's prolonged civil war. By 2004, the total number of refugees in the entire Africa continent was put between 15 and 20 million by (UNHCR, 2004). As refugees, the affected persons have been exposed to serious risks of diseases and hunger. Holsti (1983) pointed out that conflict implies subjective hostilities or tension manifesting in economic, military or aggressive hostilities. In a conflict there is also a struggle over values, scarce status, power and resources in which the conflicting parties aim to injure or eliminate their rivals. For Omotosho, (2004) most conflicts are violent, inflicting life-long injuries on their victims apart from monumental loss of lives thus the population is bound to flee in large numbers from their homes for safety or to avert starvation. Therefore it can be concluded that the conflict in South Sudan has assumed an international dimension where a significant portion of the population fled their country in search of safety and harmony.

\section{Increase in Regional Small Arms Proliferation and Cross Border Crime Rate}

Jok (2014:13) highlights the regional implications of the South Sudan conflict in relation to security issues such as the smuggling of light weapons, increasing crime rate, and fire arms proliferation. These were seen to have spill over effects that transcend the InterGovernmental Authority on Development (IGAD) region. For the rest of Africa, the broad implications of the South Sudanese crisis cannot be overemphasized as Africa cannot afford another failed state just like Somalia. Since most of the countries experience such phenomena, it could be erroneous to suggest that events in South Sudan were exceptional vis-à-vis small arms proliferation, increase in crime rate, and propagation of armed militias.

\section{Security Consequences of the Inter-Governmental Authority for Development Region}

In as far as the conflict situation is concerned; Retired Lieutenant Nyangari in an interview submits that the Inter-Governmental Authority on Development (IGAD) was compelled to intervene in a bid to resolve the South Sudanese internal conflict in an amicable way through its mediation role. However, because its decisions are arrived at through consensus it has become difficult for the group to take decisive concrete steps in order to prevent the South Sudan conflict from continuing. This has exposed the Inter-Governmental Authority on Development's (IGAD's) internal differences and weakness as each of the sub blocs and countries are pursuing and safeguarding their own interests in the process of trying to make peace in South Sudan. The Inter-Governmental Authority on Development (IGAD) member states are worried and would want to see a peace outcome that promotes their interests. Thus, the state of affairs can be likened to the 1994 Hutu-Tutsi genocide in Rwanda which adversely affected the Great Lakes region as it attempted to resolve the conflict when 
individual members had different views on how the problem could be attended to. Equally, the SADC region had similar experiences when Rwandan and Ugandan sponsored rebels invaded the Democratic Republic of Congo. The conflict in South Sudan has drastically weakened the current Inter-Governmental Authority on Development (IGAD) regional security entity as each country focuses more on safeguarding its own interests.

\section{Concluding Observations}

\section{Settling the South Sudan crisis}

According to the ICG (2014) the South Sudanese post-independence conflict requires a holistic and comprehensive solution. Basing on the evidence on the ground, South Sudan has a diverse ethnic base, consisting of the Dinka, Nuer, Lou and Shilluk inter alia. These groups have diverging views of nationhood. The only way all these groups could be accommodated in a free South Sudan is through a comprehensive peace agreement (CPA) that recognises the diverse ethnicities in the country. Blanchard (2014:3) argues that the conflict in South Sudan has become an international crisis that requires the intervention of the international community. The genocidal proportions it is increasingly taking can only be arrested through international political will. Countries such as the USA which had supported secession from Sudan should take a lead in bringing peace and stability to the country. This entails involvement of the donors and civil society in South Sudan. The civil society as the representatives of the people should help the negotiators to reach a peaceful settlement that reflects the aspirations of all the South Sudanese people.

\section{Personal Greed of the Politicians}

The study argues that the politicians in South Sudan are pursuing power, authority and control of national resources for personal benefit rather than for the betterment of the country as a whole. Therefore at the heart of the conflict in South Sudan is personal greed and private interests of the top politicians in that country. Political rivalry between Salva Kiir and Riek Machar typifies the greed and selfish interests of the political leadership. President Kiir wants to continue in office past the 2015 against the South Sudanese Constitutional provision and he is doing everything possible to frustrate Riek Machar. The two leaders are contesting to gain political dominance in South Sudan. Riek Machar's dismissal from government was as a result of this feud after he had declared his intention to challenge President Kiir in the 2015 election.

Furthermore, it is clear that ethnic polarity and the desire to access the unmet power needs are some of the major causes of conflict in South Sudan. The conflicting parties calculatingly use ethnicity and identity to mobilise communities against each other. Thus, the larger and dominant group uses the narrative of victimhood as a tool to create justifications for the cycle of violence and reprisal attacks. 
In a way, South Sudan is a victim of a dysfunctional and undemocratic domestic political system. Instead of relying on democratic systems of governance which cater for cultural and regional diversity, there is centralisation of power where the President rules by decrees. In particular the dismissal of the Cabinet and Provincial Governors, and subsequently removal of the Vice President Riek Machar and the Secretary General of the Party Pagan Amum depicts lack of compliance to the dictates of constitutional processes by the President. The president employed the SPLM's informal webs to reach a decision at the expense of the formal democratic processes provided by constitution.

The South Sudanese conflict can be attributed to deep rooted structural problems inherent in the socio-economic and political fabric of the country. Manifestations of these structural problems include widespread marginalisation of some social groups, injustice, exclusion, inequality in the distribution of the national cake and violent fanaticism. These deep rooted problems have become powerful triggers of conflict in South Sudan.

One key issue noted by this study is that that the government of South Sudan did not resolve the status of various partisan military groups after gaining independence. These diverse military entities including the SPLA, were supposed to be integrated and transformed into a unified, professional and patriotic South Sudanese National Defence Force. Each Political party that comprised the South Sudan retained a military wing that overtly maintained loyalty to its former belligerent party. In this context, such a military force could not be relied upon to defend and uphold the interests of the country. The violence rapidly spread at the outbreak of hostilities in December 2013 due to the inherent flaws in the integration of the newly formed South Sudan Peoples' Armed Forces. It became easier for Rick Machar to quickly mobilise his former troops in a reprisal move against his dismissal from government.

The study also noted that there was an external hand in the South Sudanese conflict. Sudan still believes that South Sudan is essentially part of it, and therefore has played a role in the outbreak of the conflict due to vested interests. South Sudan has rich oil resources which has been the main lifeblood of the then united Sudan. President al Bashir's support for Riek Machar is aimed at gaining access to North Bentiu oil fields located between the common frontiers of the two nation-states. Besides, Riek Machar's has kept good relations with Sudan from the time he defected from SPLM in 1991 and joined Khartoum government to fight against the SPLM of John Garang. Further, the Chinese and the Americans have been involved in the South Sudanese conflict to promote their global interests.

The conflict in South Sudan has caused serious suffering and destruction across the country. Many innocent people have lost their lives, socio-cultural connections, and their possessions have been massively damaged. The ethnic hostilities have divided communities, heightened the levels of mistrust, and thus making reconciliation almost impossible. On the other hand, the conflict had seen the proliferation of small arms and numerous militia groups leading to an increase in the rate of crime. The conflict has had an effect on economic growth and development. Countries of the Inter-Governmental Authority on Development (IGAD) 
region are expending more on the purchase of military hardware to fight the ongoing civil war in South Sudan. In neighbouring countries, more military resources are being acquired to curtail cross border incursions by belligerents at the expense of public goods. In addition, the conflict in South Sudan has significantly reduced oil production output by 40 percent from at least 200,000 barrels per day (b/d) to approximately 150,000 b/d in January 2014. As mentioned earlier, the current conflict in South Sudan has spawned a regional refugee crisis. An estimated one million people have been displaced by the fighting. More than 400,000 people have fled to neighbouring countries, Ethiopia, Kenya, Sudan and Uganda as refugees. These countries are failing to cope with the upkeep demands, food, shelter, and health and security demands of these refugees estimated to around 1.5 million. Conditions in the refugee camps are deplorable and they have become death traps rather than safe zones. The conflict in South Sudan has led to displacements, and has precipitated other colossal social ills such as; poverty, starvation, loss of lives and socio-cultural disruption and educational deprivation for school going children.

The conflict in South Sudan has caused a massive exodus of thousands of Ugandan and Kenyan nationals who were working in the construction and service sectors in that country. For a country that heavily relied on skilled expatriate labour force mainly from Uganda and Kenya, the outbreak of the civil war was a blow as expatriate workers went back home. In essence, the South Sudan economy suffered severely from massive loss of skilled labour force while the Ugandan fiscus was dealt a major blow as remittances coming from Ugandans working in South Sudan were no longer forthcoming. The crisis in South Sudan is an additional burden to the Inter-Governmental Authority on Development (IGAD) region which is already grappling with conflicts in Somali, Sudan, Uganda, Djibouti and Ethiopia. In fact, each of the seven member states of the Inter-Governmental Authority on Development (IGAD) is facing internal strife and the conflict in South Sudan is an unwelcome phenomenon economically, socially, politically, militarily, and common sense of peace and security

The other major implication of the ongoing conflict in South Sudan is that the fighting has affected effective economic integration within the East African Economic Community. The conflict has frustrated the signing of the Lamu Port-South Sudan-Ethiopia Transport Corridor (LAPSSET) project between Kenya, Sudan, Ethiopia and South Sudan. This pipeline project was developed to transport oil from South Sudan through Sudan, Ethiopia and Kenya.

\section{Need for a Comprehensive Peace Agreement}

There is need for a comprehensive peace agreement that takes on board all the relevant stakeholders. This entails inclusive peace talks that embrace all stake holders, political players, and belligerent parties irrespective of their inclination or size in the current peace talks. Ethnicity is one of the key driving forces in the on-going conflict in South Sudan. There is therefore need for a national healing process through reconciliation modelled 
${ }^{1}$ John Max Chinyanganya \& ${ }^{2}$ Johns Mhlanga

along the lines of the South African Truth and Reconciliation Commission once peace has been secured. A Truth and Reconciliation Commission will provide a platform for all the victims and perpetrators to meet and forgive each other. The UN (2014:3) contends that much can be drawn from countries such as Burundi and Rwanda. Burundi and Rwanda experienced ethnic conflict in the 1990s and have since implemented various measure aimed at reconciling warring parties. The comprehensive peace agreement should also provide for a democratic constitution and order with clear guidelines on governance issues such as separation of power, rather than use decrees or webs of informal means to reach decisions.

\section{Negotiations should Reach beyond Political Elites}

The peace negotiations in South Sudan should reach beyond the political elites and the armed groups. State level actors such as the bureaucrats in government must be consulted, engaged and informed about the negotiation agenda, issues, and options for agreement. This also means that Members of Parliament (MPs) should be briefed regularly so that they can explain to their constituencies the trajectory of the negotiation process. The civil society in South Sudan should take a lead in shaping the negotiation process. The civil society participation ensures or guarantees that the ordinary South Sudanese citizenry can monitor and evaluate the negotiation process. This ensures that whatever peace deal is arrived at, reflects the aspirations of the people of South Sudan. The problem with the peace process in South Sudan is that it mainly involves the political elites and military groups who often advance narrow self-interests. Thus, civil society should have a robust role in the South Sudanese peace process as they serve as a mechanism for citizenry input, to the mediators, negotiators, and the monitoring of key deliberations.

\section{References}

Akinboye, S., \& Ottoh, F. (2007). A systematic approach to international relations. Nigeria: Lagos Press.

Appleby, R. (2000). The ambivalence of the sacred religion: Violence and reconciliation. Rowman and Littlefield Publishers.

Ball, N. (1991). Pressing for Peace: Can aid induce reform? Washington, DC: Overseas Publishers.

Banks, M. (1984). Conflict in world society. London: Wheatsheaf Publisher.

Burton, J.W., \& Dukes, F. (1990). Conflict: Practices in management, settlement and resolution conflict series. London: Macmillan Publishers.

Burton, J.W. (1993). Conflict resolution theory and practice: Integration and application. New York: Manchester University Press.

Burton, J. W. 1990. Conflicts: Human needs theory. New York: St. Martin's Press.

Buzan, B. (1997). People, states and fear, the national security problem in the international relations. USA:Boulder Lynn Printers. 
Buzan, B., \& Waever, O. (2003). Regions and powers, the structure of international security. Cambridge: University Press.

Creswell, J. W. (2007). Research design: Qualitative, qualitative and mixed approaches. New York: Oaks Sage Publishers.

Deng, F. (2014). New Sudan in the making, a nation in painful search of itself. Asmara: Red Sea Press.

Douglas, J. (2012). The root causes of Sudan's civil wars: Peace or truce. African Issues. Cape Town Publishers

Gray, D. E. (2005). Doing research in the real world: London: Sage Publications.

Galtung, J. (2000). Searching for peace: London: Pluto Press.

Haider, H. (2011). Factors contributing to transitional justice, effectiveness, governance and social development. UK: Birmingham Press.

Hwaly, S. (2009). Conflict management in Africa and weapon proliferation. New York: Boydell and Brewert Press.

Holsti, O. (1983). Dynamic and images of enemy in politics. USA: Chicago Press.

Huntington, S. 1996. The clash of civilizations. New York: Simon \& Schuster Printers.

Jeong, H. W. (2010). Concepts of peace and violence in peace and conflict studies: An Introduction. England: Ashgate Publishers.

Kellas, J. (1991). The politics of nationalism and ethnicity. New York: St. Martin Press.

Kifle, L. (2007). Governing guns, preventing plunder of resources. Oxford: University Press.

Leonardi, C. Nelson, L., \& Santschi, M. (2010). Justice in Southern Sudan. Isser Peace Press.

Ludsin, H. 2011. Peacemaking and constitution-drafting: A dysfunctional marriage. London: Longman Publishers.

Lyman, .N. (2014). Crisis and opportunity in South Sudan. USA: Institute of Peace Press.

Martel, L. (2014). Our hearts Sudan and South Sudan should remain Interdependent. Cambridge: Polity Press.

Meredith, M. (2011). The state of Africa. Lagos: Concepts Publishers.

Nhema, A., \& Zeleza, F. (2008). The resolution and conflict management in Africa Newman, E., \& Richmond, O. (2006). Peace building and spoilers. Conflict security and development. Massachusetts, Harvard Press.

Omotosho, F. (2004). Putting facts of the conflict in perspective. Nigeria: Frisky Larr Publisher.

Oppenheim, L. (1992). International crisis and African perspective. Essex UK, Longman Ottaway, M., \& El-Sadany, O. (2012). Sudan from conflict to conflict, endowment for international peace. Washington: Sage Press.

Reeve, R. (2014). Peace and conflict assessment. London: International Alert Press.

Rothschild, L. (2003). Ethno politics: A conceptual framework. Columbia University Press. Ruay, D. (1994). Post-colonial state and civil war in Sudan. US: IB Tauris Publishers. Scupin, J. \& Decorse, E. (2004). Hand book of social relations. Oxford: Publishers.

Stedman, S. J. (2002). Spoilers problems in peace process international security. Boulders Publications. 
${ }^{1}$ John Max Chinyanganya \& ${ }^{2}$ Johns Mhlanga

Tadessa, M. (2002). US foreign policy and the horn of Africa. Addis Ababa Meagre Printing. Tull, D. M., \& Mehler, A. (2005). The hidden costs of power-sharing: Reproducing insurgent violence in Africa. Cape Publishers.

Varshney, P. (2002). Hand book of ethnic conflict in India science and business media. New Dehli: Yale Press.

Webel, D., \& Galtung, J. (2007). Hand book of peace and conflict studies. New York: Tailor and Francis Publishers.

Zartman, W. (1991). Conflict resolution and management. Washington DC: Brookings Institution . 